\title{
Characterization and Inhibitory Effects of Magnetic Iron Oxide Nanoparticles Synthesized from Plant Extracts on HeLa Cells
}

\author{
Bernard Owusu Asimeng, ${ }^{1}$ Emmanuel Nyankson, ${ }^{2}$ Johnson Kwame Efavi $\mathbb{D},{ }^{2}$ \\ Amartey Nii Amarkai, ${ }^{2}$ Gloria Pokuaa Manu, ${ }^{2}$ and Elvis Tiburu ${ }^{1}$ \\ ${ }^{1}$ University of Ghana, School of Engineering Sciences, Department of Biomedical Engineering, P.O. Box LG 74, Accra, Ghana \\ ${ }^{2}$ University of Ghana, School of Engineering Sciences, Department of Materials Science \& Engineering, P.O. Box LG 74, \\ Accra, Ghana
}

Correspondence should be addressed to Johnson Kwame Efavi; jkefavi@ug.edu.gh

Received 3 August 2020; Revised 17 November 2020; Accepted 26 November 2020; Published 10 December 2020

Academic Editor: Wen-Cheng Chen

Copyright (c) 2020 Bernard Owusu Asimeng et al. This is an open access article distributed under the Creative Commons Attribution License, which permits unrestricted use, distribution, and reproduction in any medium, provided the original work is properly cited.

\begin{abstract}
Magnetic $\mathrm{Fe}_{3} \mathrm{O}_{4}$ nanoparticles were synthesized from maize leaves and plantain peels extract mediators. Particles were characterized, and the inhibitory effects were studied on HeLa cells in vitro using cyclic voltammetry (CV). Voltammograms from the $\mathrm{CV}$ show that $\mathrm{Fe}_{3} \mathrm{O}_{4}$ NPs interaction with $\mathrm{HeLa}$ cells affected their electrochemical behavior. The nanoparticles formed with higher $\mathrm{Fe}^{3+} / \mathrm{Fe}^{2+}$ molar ratio $(2.8: 1)$ resulted in smaller crystallite sizes compared to those formed with lower $\mathrm{Fe}^{3+} / \mathrm{Fe}^{2+}$ molar ratio $(1.4: 1)$. The particles with the smallest crystallite size showed higher anodic peak currents, whereas the larger crystallite sizes resulted in lower anodic peak currents. The peak currents relate to cell inhibition and are confirmed by the half-maximum inhibitory concentration $\left(\mathrm{IC}_{50}\right)$. The findings show that the particles have a different inhibitory mechanism on HeLa cells ion transfer and are promising to be further exploited for cancer treatment.
\end{abstract}

\section{Introduction}

Nanomedicine has shown a promising potential in clinical usage against a number of human diseases (cancer, diabetes, hypotension, etc.), with the development of nanoscale materials for use in biological applications, notably cancer therapeutics [1-5]. Among the numerous nanoscale materials for cancer diagnostics and treatment applications, magnetic nanoparticles (NPs) have emerged the most potent, and their magnetic properties have been exploited in magnetic resonance imaging (MRI), biosensors applications [6-12]. These magnetic nanoparticles in cancer treatment can be controlled to specific cancer sites for drugs to be delivered using external magnetics. Also, in the detection of cancer growth, MRI can be used to scan body parts or the materials can be designed by embedding them with receptors that are attracted to cancer cell.
Biological applications of magnetic nanoparticles have emerged as the material of interest due to their crystal inverse spinel crystal structure as well as their biocompatibility, superparamagnetic nature, and surface modification properties coupled with their unique physical, chemical, mechanical, and thermal features $[13,14]$.

Several methods have been employed in the synthesis of magnetic $\mathrm{Fe}_{3} \mathrm{O}_{4}$ nanoparticles $\left(\mathrm{Fe}_{3} \mathrm{O}_{4} \mathrm{NPs}\right)$ including forced hydrolysis, hydrothermal technique, micro emulsion, and sol-gel methods. Co-precipitation synthesis approach is the simplest and most efficient method reported in literature [12, 15-18]. These chemical methods though have high yields of nanomaterials produced within a short time, they are expensive, and the chemicals involved are hazardous and produce toxic waste byproducts. There has been great interest in green synthesis of nanoparticles through biological means and its importance is well documented in literature 
$[19,20]$. This interest is mostly fueled by the ability to synthesis nanoparticles without the use of toxic chemicals and involvement of hazardous byproducts.

Current novel approaches which are still under development use plant extract and other microorganisms such as algae, bacteria, actinomycetes, yeast, and fungi which results in environmentally friendly and biocompatible benign particles [18]. Plant extracts are generally much more of interest in biosynthesis because their throughput in nanoparticle production is much higher than the use of microbes and plant parts are also easily available [21, 22]. Plants naturally come equipped with bioactive molecules that act as reducing and stabilizing agents for inorganic iron salts employed in nanoparticle production $[23,24]$. It is also reported that the nature of bioactive molecules present in plant extract has varying degrees of effect on the type and morphology of magnetic nanoparticles produced and they also influence the reactive mechanism of the metal salt reduction and stabilization process, especially where a combination of ferric $\left(\mathrm{Fe}^{3+}\right)$ and ferrous $\left(\mathrm{Fe}^{2+}\right)$ salts are used $[25,26]$. The standard $\mathrm{Fe}^{3+} / \mathrm{Fe}^{2+}$ molar ratio for the formation of $\mathrm{Fe}_{3} \mathrm{O}_{4}$ nanoparticles to achieve the inverse spinel crystal structure is $2: 1$.

Maize and plantain are common tropical plants varieties whose fruits are consumed but their leaves and other parts are disposed as waste. In this work, we have synthesized $\mathrm{Fe}_{3} \mathrm{O}_{4}$ NPs from maize leaves and plantain peels using different molar ratios of $\mathrm{Fe}^{3+} / \mathrm{Fe}^{2+}$ and evaluated their biological interactions with HeLa cancer cells. The properties of the synthesized nanoparticles have been examined using $\mathrm{x}$-ray diffraction (XRD), scanning electron microscopy (SEM), energy dispersive $\mathrm{x}$-ray spectroscopy (EDX), UVvisible spectroscopy (UV-Vis), and Fourier-transform infrared (FTIR). The biological interaction of these particles with HeLa cancer cells has been established using a cyclic voltammetry.

\section{Materials and Methods}

2.1. Raw Materials. All the reagents used in this work including ferrous chloride $\mathrm{FeCl}_{2} \cdot 4 \mathrm{H}_{2} \mathrm{O}$ (M.W. 198.81), ferric chloride $\mathrm{FeCl}_{3} \cdot 6 \mathrm{H}_{2} \mathrm{O}$, and sodium hydroxide $(\mathrm{NaOH})$ were of analytic grade and purchased from Sigma Aldrich, UK.

2.2. Preparation of Plant Extracts. Maize leaves, plantain leaves, and plantain peels used in this experiment were sampled from Ayido Flat E plantation farm on University of Ghana campus, Legon.

In preparing the extracts, each plant part was washed, cut into smaller sizes, and dried in a GeblabPrime oven at $60^{\circ} \mathrm{C}$ for 3 days, after which they were then ground/milled into powder using an Ika A111B mill. The grinding was done for approximately 10 minutes. $20 \mathrm{~g}$ of the powder was measured into a $300 \mathrm{~mL}$ beaker and $200 \mathrm{~mL}$ of distilled water added. The mixture was fluxed at $70^{\circ} \mathrm{C}$ for 1 hour, with continuous stirring. The mixture was then filtered with a cheesecloth and then with filter paper. The extract obtained was then stored at $-4^{\circ} \mathrm{C}$ before use [27].

2.3. Synthesis of Magnetic $\mathrm{M}-\mathrm{Fe}_{3} \mathrm{O}_{4}$ Nanoparticles. The preparation of $\mathrm{Fe}_{3} \mathrm{O}_{4}$ NPs followed an already established procedure in literature [28-30]. In this work, molar ratio $\mathrm{FeCl}_{3}$ hexa-hydrate and $\mathrm{FeCl}_{2}$ tetra-hydrate was used in a batch formation of $2.8: 1$ and $1.4: 1\left(\mathrm{Fe}^{3+} / \mathrm{Fe}^{2+}\right)$ mixture as shown in Table 1. The batch mixture of the precursors was dissolved in $200 \mathrm{ml}$ of distilled water and stirred for 20 minutes. $40 \mathrm{ml}$ of the extract was then added to the precursor solution changing the color of the solution from pale yellow to dark green (plantain peels extract) and light black (maize leaves extract). A $2.0 \mathrm{M} \mathrm{NaOH}$ solution at a rate of $3 \mathrm{~mL} / \mathrm{min}$ was added for uniform formation of the magnetic $\mathrm{Fe}_{3} \mathrm{O}_{4}$ nanoparticles until $\mathrm{pH}$ of 11 was attained. The solution color changed to brown when $\mathrm{pH}$ was in the range of 3-4 and to black when $\mathrm{pH}$ was within 8-11. After complete nucleation of the nanoparticles, the black colored nanoparticles formed were labelled as plantain peels $\mathrm{Fe}_{3} \mathrm{O}_{4} \mathrm{NPs}$ ( $\mathrm{PP}-\mathrm{Fe}_{3} \mathrm{O}_{4} \mathrm{NPs}$ ) and maize leaves $\mathrm{Fe}_{3} \mathrm{O}_{4} \mathrm{NPs}\left(\mathrm{ML}-\mathrm{Fe}_{3} \mathrm{O}_{4} \mathrm{NPs}\right)$. The nanoparticles were then immobilized using an external magnet. Distilled water was used to wash the particles 3 times and the washed particles were then freeze-dried.

2.4. Characterization of $\mathrm{Fe}_{3} \mathrm{O}_{4}$ Nanoparticles. The crystal growth planes and crystallite sizes were determined using $\mathrm{X}$-ray diffraction (XRD). The analysis was conducted using X'Pert PRO x-ray Diffractometer (PanAnalytical) operating with $\mathrm{Cu} \mathrm{K}-\alpha$ radiation (wavelength of $1.544 \AA$ ) at $45 \mathrm{kV}$ and $40 \mathrm{~mA}$ with a $20-70^{\circ} 2 \theta$ range, a $0.2^{\circ}$ step width scanning $1.2 \mathrm{deg} / \mathrm{min}$ on a $2 \mathrm{~g}$ sample. The absorbance was measured using a UV-Vis spectrophotometer (Thermo Fisher Scientific, China) operating within a scanning range of $300-800 \mathrm{~nm}$ with a $5 \mathrm{~nm}$ scan step on a $3 \mathrm{ml}$ sample. The surface morphology of the samples was studied using a scanning electron microscope (SEM), Phenom desktop SEM with EDX analysis software. The Fourier-transform infra-red spectroscopy was performed using a PerkinElmer spectrum 2 spectrometer (PerkinElmer Inc., UK) with a 4000$400 \mathrm{~cm}^{-1}$ scanning range and $4 \mathrm{~cm}^{-1}$ resolutions on a $0.1 \mathrm{~g}$ sample.

2.5. Cell Viability Studies. HeLa cells were cultured in RPMI640 medium supplemented with $10 \%$ FBS, 1\% PS, and incubated at $37^{\circ} \mathrm{C}$ and $5 \% \mathrm{CO}_{2}$. Cells $(n=3)$ were grown differently for 48 hours and each cell density was normalized using the inhibition rate factor given by (1)-(treated cell viability/untreated cell viability) ${ }^{*} 100 \%$. Thereafter, the nanoparticles were introduced into the cells and CV measurements were taken after 30 minutes. A quantity of $2.0 \mathrm{mg}$ $\mathrm{Fe}_{3} \mathrm{O}_{4}$ nanoparticles (NPs) was mixed with $40 \mathrm{ml}$ of phosphate buffer saline (PBS) and vortexed for $3 \mathrm{~min}$ to yield a stock solution. Volume of $5 \mu \mathrm{L}$ from the stock solution was added to $100 \mu \mathrm{L}$ of HeLa Cells. The mixture was allowed for 
TABLE 1: The molar ratio of precursors used for the synthesis of nanoparticles.

\begin{tabular}{|c|c|c|c|c|}
\hline Extract used & $\mathrm{Fe}^{3+}$ mass used & $\mathrm{Fe}^{2+}$ mass used & $\mathrm{Fe}^{3+} / \mathrm{Fe}^{2+}$ & Sample name \\
\hline \multirow{2}{*}{ Maize leaves } & 5.52 & 1.98 & $2.8: 1$ & $\mathrm{ML} 1-\mathrm{Fe}_{3} \mathrm{O}_{4} \mathrm{NPs}$ \\
\hline & 10.82 & 7.97 & $1.4: 1$ & $\mathrm{ML} 3-\mathrm{Fe}_{3} \mathrm{O}_{4} \mathrm{NPs}$ \\
\hline \multirow{2}{*}{ Plantain peels } & 5.52 & 1.98 & $2.8: 1$ & $\mathrm{PP} 1-\mathrm{Fe}_{3} \mathrm{O}_{4} \mathrm{NPs}$ \\
\hline & 10.82 & 7.97 & $1.4: 1$ & $\mathrm{PP} 3-\mathrm{Fe}_{3} \mathrm{O}_{4} \mathrm{NPs}$ \\
\hline
\end{tabular}

30 min incubation, after which $5 \mu \mathrm{L}$ was added to $\mathrm{Ag} / \mathrm{AgCl}$ interdigitated electrode (DropSens, UK) for cyclic voltammetry $(\mathrm{CV})$ analysis.

\section{Results and Discussion}

The results obtained from the characterization of the synthesized particle (ML- $\mathrm{Fe}_{3} \mathrm{O}_{4} \mathrm{NPs}$ and $\mathrm{PP}-\mathrm{Fe}_{3} \mathrm{O}_{4} \mathrm{NPs}$ ) and their effect on HeLa Cells (modelled cancer cells) are displayed and discussed. Fourier-transform infra-red spectroscopy (FTIR) x-ray diffraction (XRD), scanning electron microscopy (SEM), energy-dispersive $\mathrm{x}$-ray spectroscopy (EDX), and cyclic voltammetry (CV) characterizations are reported below.

3.1. Fourier-Transform Infrared Spectroscopy (FTIR). FTIR spectroscopy studies were used to identify the functional groups associated with bioactive molecules present in the maize leaves and plantain peels extract which acted as both reducing and stabilization agents in the synthesis of the $\mathrm{Fe}_{3} \mathrm{O}_{4}$ NPs. The FTIR spectra of synthesized NPs obtained were within $3500-450 \mathrm{~cm}^{-1}$. The spectra of the extracts shown in Figure 1 revealed strong absorption bands at $\sim 3348 \mathrm{~cm}^{-1}, \sim 2921 \mathrm{~cm}^{-1}, \sim 2845 \mathrm{~cm}^{-1}, \sim 1637 \mathrm{~cm}^{-1}$, and $\sim 1036 \mathrm{~cm}^{-1}$. The region of $\sim 3348 \mathrm{~cm}^{-1}$ displayed bands corresponding to- $\mathrm{OH}$ (of phenol compound) stretching vibrations. The absorption peaks at $\sim 2921 \mathrm{~cm}^{-1}$ and $2845 \mathrm{~cm}^{-1}$ are associated with the $\mathrm{sp} 3 \mathrm{C}-\mathrm{H}$ stretching vibrations of the $-\mathrm{CH}_{2}$ functional group [31]. The peak at $\sim 1637 \mathrm{~cm}^{-1}$ represents N-H bending of amide group and the peak at $\sim 1036 \mathrm{~cm}^{-1}$ corresponds to C-N stretching of aliphatic amines [32]. It is also observed in Figure 1 that the strength of absorption or intensity is stronger for the plantain peels than the maize leaves indicating that the phytochemicals identified are rich in the plantain peels compared to the maize leaves.

Absorbance bands of the synthesized $\mathrm{Fe}_{3} \mathrm{O}_{4}$ NPs were observed at $\sim 3340 \mathrm{~cm}^{-1}, \quad \sim 1640 \mathrm{~cm}^{-1}, \quad \sim 1063 \mathrm{~cm}^{-1}$, $\sim 900 \mathrm{~cm}^{-1}$, and $\sim 544 \mathrm{~cm}^{-1}$. The reduction in the intensity of band $3500 \mathrm{~cm}^{-1}-3214 \mathrm{~cm}^{-1}$ in the extracts shows the involvement of the phenol compounds in the reduction of the ferrous and ferric chloride precursors. Based on the reduction in band intensities at $\sim 1637$ and $\sim 1036 \mathrm{~cm}^{-1}$, proteins are also involved in the reduction of the ferrous and ferric chloride precursors. The presence of the peak at $\sim 544 \mathrm{~cm}^{-1}$ corresponds to stretching vibrations of $\mathrm{Fe}-\mathrm{O}$ bonds depicting the presence of $\mathrm{Fe}_{3} \mathrm{O}_{4}$ [33]. The FTIR results, shown in Figures 1 and 2, all indicate that the bioactive elements present in the maize leaves and plantain peels leaves extracts could have been reducing and stabilizing

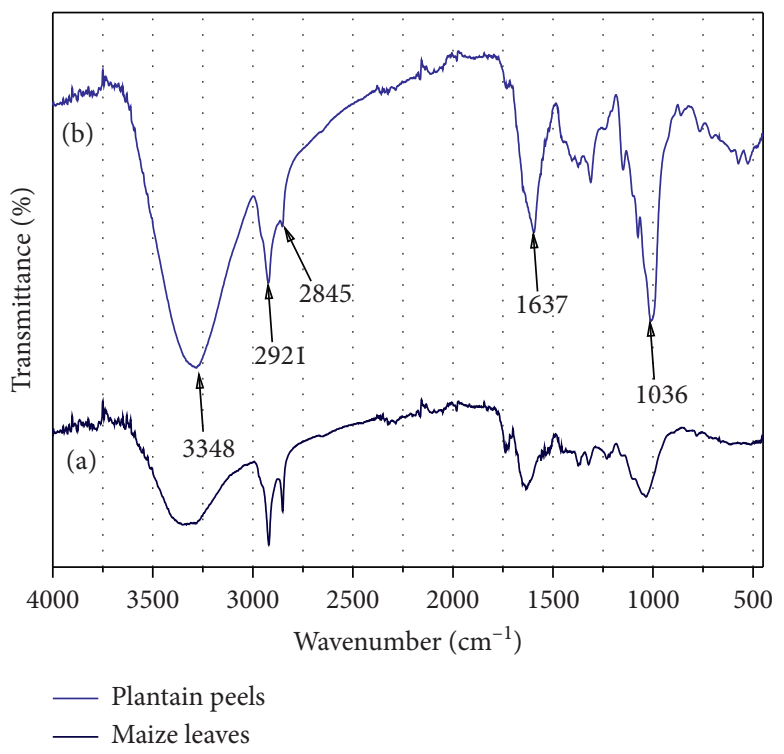

FIgURE 1: FTIR plot of extracts used in the synthesis. (a) Maize leaves. (b) Plantain peels.

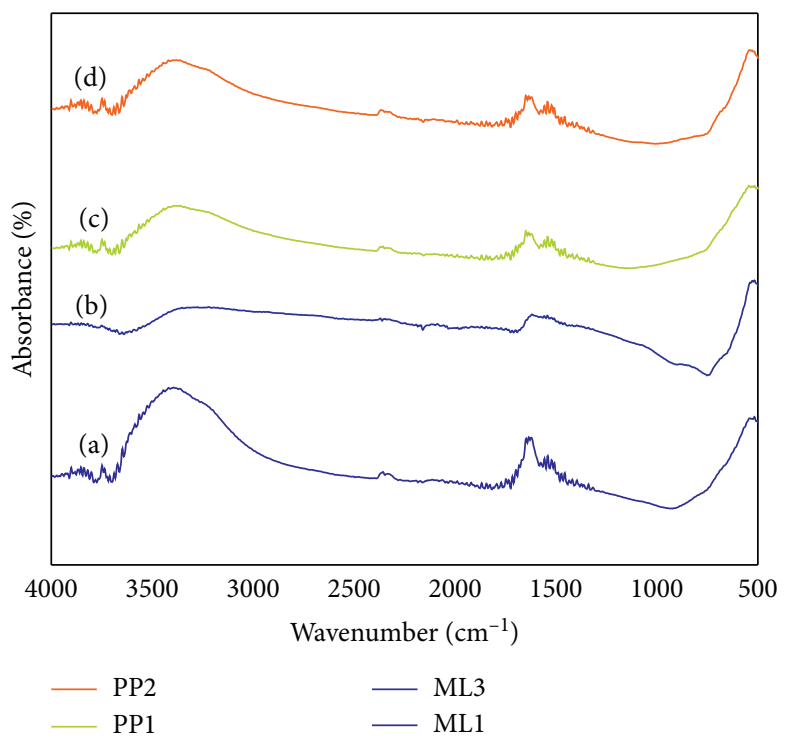

FIGURE 2: FTIR of plantain peels and maize leaves synthesized. (a) $\mathrm{ML1}-\mathrm{Fe}_{3} \mathrm{O}_{4}$ NP. (b) $\mathrm{ML} 3-\mathrm{Fe}_{3} \mathrm{O}_{4}$ NP. (c) PP1- $\mathrm{Fe}_{3} \mathrm{O}_{4}$ NP. (d) PP3$\mathrm{Fe}_{3} \mathrm{O}_{4} \mathrm{NP}$.

agents in the synthesis process. The proteins and phenol compounds are believed to have been involved in the formation of $\mathrm{Fe}_{3} \mathrm{O}_{4}$. The formation and unique characteristics of $\mathrm{Fe}_{3} \mathrm{O}_{4}$ are as a result of electron transfer between $\mathrm{Fe}^{3+}$ and $\mathrm{Fe}^{2+}$ ions in tetrahedral and octahedral sites of the crystal 
lattice formed $[28,29]$. It is established that a molar ratio of $2: 1\left(\mathrm{Fe}^{3+} / \mathrm{Fe}^{2+}\right)$ mixture is a precondition for the formation of $\mathrm{Fe}_{3} \mathrm{O}_{4} \mathrm{NPs}$ due to reaction mechanisms [30, 34]; however, the crystallization process may be affected by the presence of phytochemicals in the plant extract acting as stabilization and reducing agents in the reaction mechanism which can lead to variation in the molar ratios required in the formation of $\mathrm{Fe}_{3} \mathrm{O}_{4}$ nanoparticles.

3.2. X-Ray Diffraction (XRD). $\mathrm{Fe}_{3} \mathrm{O}_{4}$ NPs were characterized by $\mathrm{X}$-ray powder diffraction and patterns were collected to identify phases and crystalline structure and the results are presented in Figure 3. In total, it was found that there were intense diffraction peaks indexed (220), (311), (400), (422), (511), (440), and (533) at 2 theta values of $30.1^{\circ}, 35.5^{\circ}$, $43.1^{\circ}, 54.5^{\circ}, 57.6^{\circ}, 62.8^{\circ}$, and $74.2^{\circ}$, respectively. The standard XRD data for magnetic iron oxide having a face-centered cubic structure was similar to the recorded data. The different molar ratios of $2.8: 1$ and $1.4: 1$ of $\mathrm{Fe}^{3+} / \mathrm{Fe}^{2+}$ used in the synthesis affected crystallites sizes of the nanoparticles obtained. It is established that the formation and unique characteristics of $\mathrm{Fe}_{3} \mathrm{O}_{4}$ are as a result of electron transfer between $\mathrm{Fe}^{3+}$ and $\mathrm{Fe}^{2+}$ ions in tetrahedral and octahedral sites of the crystal lattice formed [28, 29]. It is established that a molar ratio of $2: 1\left(\mathrm{Fe}^{3+} / \mathrm{Fe}^{2+}\right)$ mixture is a precondition for the formation of $\mathrm{M}-\mathrm{Fe}_{3} \mathrm{O}_{4} \mathrm{NPs}$ due to reaction mechanisms [30, 34]. It is also established that the crystallization process may be affected by the presence of the stabilization and reducing agents in the reaction mechanism leading to variation in the molar ratios required in the formation of $\mathrm{Fe}_{3} \mathrm{O}_{4}$ nanoparticles synthesized from green bioactive sources.

With the aid of the Debye-Scherrer relation, crystallite sizes were estimated using

$$
D=\frac{0.89 \lambda}{\beta \cos \theta},
$$

where $D$ represents the average crystallite size, $\lambda$ represents the wavelength of the $\mathrm{Cu}-\mathrm{K}$ irradiation, $\beta$ represents FWHM of the most intense of the peak, and $\theta$ represents the diffraction angle of the (311) peak of the magnetic $\mathrm{Fe}_{3} \mathrm{O}_{4} \mathrm{NPs}$.

Table 2 presents the extracted peak intensity position and calculated crystal sizes. The crystallite sizes calculated from the XRD data indicate that for a decrease in the molar $\mathrm{Fe}^{3+}$ / $\mathrm{Fe}^{2+}$ ratio the crystallite sizes increased.

It can be observed that the crystallite sizes of the $\mathrm{Fe}_{3} \mathrm{O}_{4}$ NPs formed with higher $\mathrm{Fe}^{3+} / \mathrm{Fe}^{2+}(2.8: 1)$ molar ratios are smaller compared with those formed with lower ratios of $\mathrm{Fe}^{3+} / \mathrm{Fe}^{2+}(1.4: 1)$. The crystallite size of $\mathrm{Fe}_{3} \mathrm{O}_{4} \mathrm{NPs}$ has been prepared from Cynara cardunculus leaf using ferric chloride and ferrous chloride of a molar ratio of $1: 2 \mathrm{M}$ and obtained crystallite size of $13.5 \mathrm{~nm}$ [31]. The result is similar to the crystallite size obtained in this work for $\mathrm{Fe}_{3} \mathrm{O}_{4} \mathrm{NPs}$ extracted with lower molar ratios of $\mathrm{Fe}^{3+} / \mathrm{Fe}^{2+}(1.4: 1)$. An appreciable decrease in the crystallite size is observed when the molar ratio of the precursors is increased to a high malar ratio (2.8: 1 ) and the observation is in line with works reported in

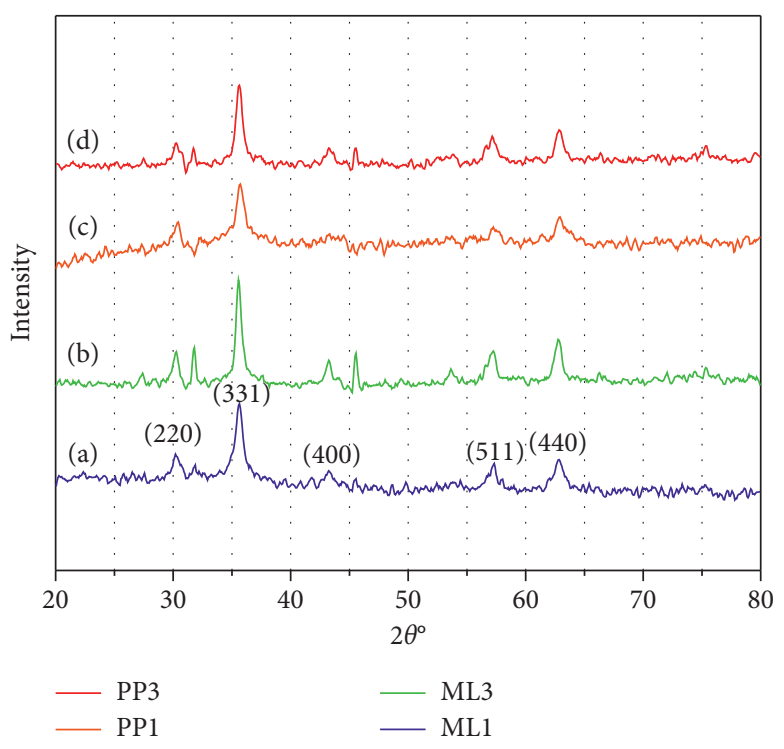

FIgURE 3: XRD pattern of $\mathrm{Fe}_{3} \mathrm{O}_{4}$ NPs synthesized with molar ratios $2.8: 1$ and $1.4: 1$. (a) $\mathrm{ML} 1-\mathrm{Fe}_{3} \mathrm{O}_{4}$ NPs. (b) $\mathrm{ML}_{3}-\mathrm{Fe}_{3} \mathrm{O}_{4}$ NPs. (c) PP1$\mathrm{Fe}_{3} \mathrm{O}_{4}$ NPs. (d) $\mathrm{PP} 3-\mathrm{Fe}_{3} \mathrm{O}_{4}$ NPs.

TABle 2: Magnetic nanoparticles prepared and their corresponding crystallite sizes.

\begin{tabular}{lccc}
\hline Sample & FWHM & Peak position & Crystallite size $(\mathrm{nm})$ \\
\hline ML1-FeNPs & 1.23489 & 35.59 & 7.05 \\
ML3-FeNPs & 0.62413 & 35.56 & 13.96 \\
PP1-FeNPs & 1.08648 & 35.72 & 8.02 \\
PP3-FeNPs & 0.71084 & 35.63 & 12.26 \\
\hline
\end{tabular}

FWHM: full width half maximum.

literature $[32,33]$. The high molar ratio prevents good agglomeration of the crystallites and thus decreases the size.

3.3. Energy Dispersive X-Ray (EDX) and Scanning Electron Microscopy (SEM). The EDX data obtained from the synthesized particles suggested in most of the particles formed that there were other elements besides Fe and $\mathrm{O}$, mostly $\mathrm{Na}$ and $\mathrm{Cl}$, which also was evident in XRD by the display of peaks around 2 theta angles of $32^{\circ}$ and $45.5^{\circ}$. The presence of these peaks is as a result of $\mathrm{Na}$ in $\mathrm{NaOH}$ alkaline and $\mathrm{Cl}$ from the iron salts used in the synthesis. The EDX and SEM analysis of each sample are present in Figures 4-7. In addition, the EDX results in Figures 4(a), 5(a), 6(a), and 7(a) show the presence of other elements: calcium, silicon, magnesium, and potassium, which might be associated with the plant extracts.

The scanning electron microscopy (SEM) images display different texture and morphology for the different molar ratios of $\mathrm{Fe}^{3+} / \mathrm{Fe}^{2+}$ used in the $\mathrm{Fe}_{3} \mathrm{O}_{4}$ nanoparticles synthesized. The texture and morphology of $\mathrm{ML1}-\mathrm{Fe}_{3} \mathrm{O}_{4} \mathrm{NPs}$ and $\mathrm{PP} 1-\mathrm{Fe}_{3} \mathrm{O}_{4}$ NPs in Figures 4(b) and 5(b), respectively, are observed to be finer and agglomerated compared to a more coarser regular shaped $\mathrm{ML} 3-\mathrm{Fe}_{3} \mathrm{O}_{4} \mathrm{NPs}$ and PP3$\mathrm{Fe}_{3} \mathrm{O}_{4}$ NPs in Figures 6(b) and 7(b), respectively. These two 


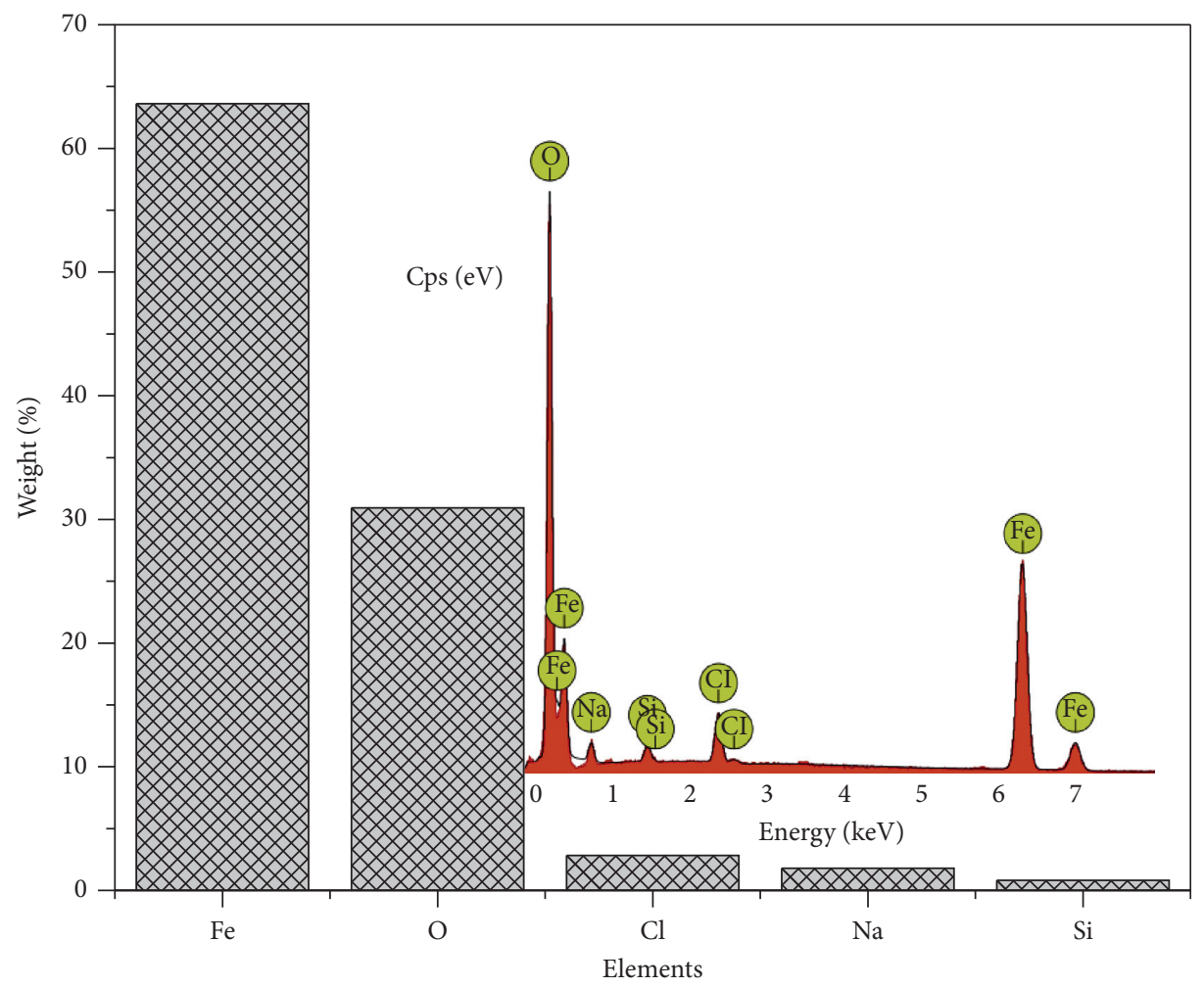

(a)

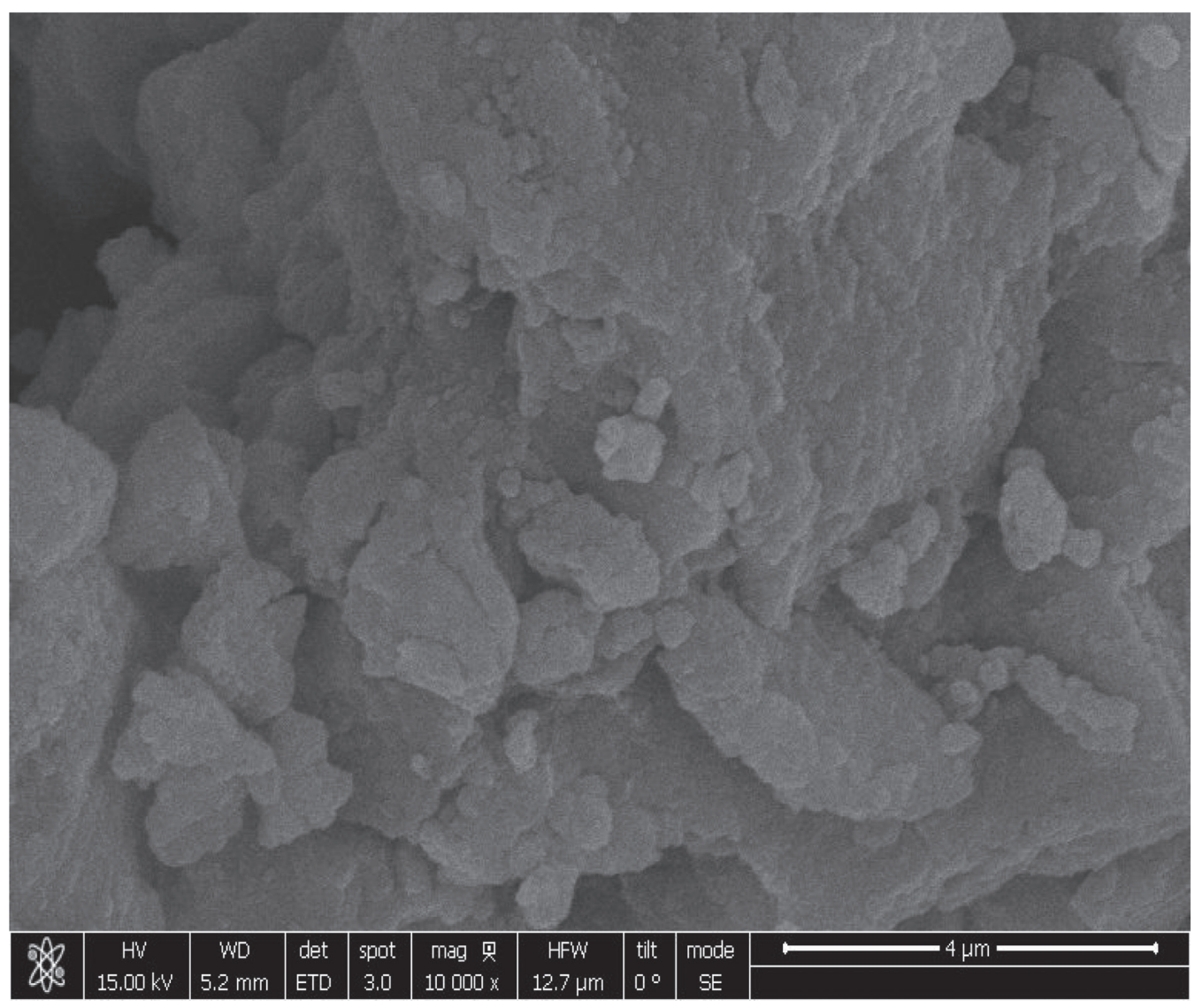

(b)

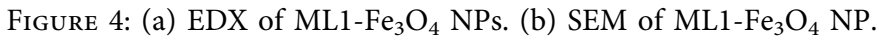




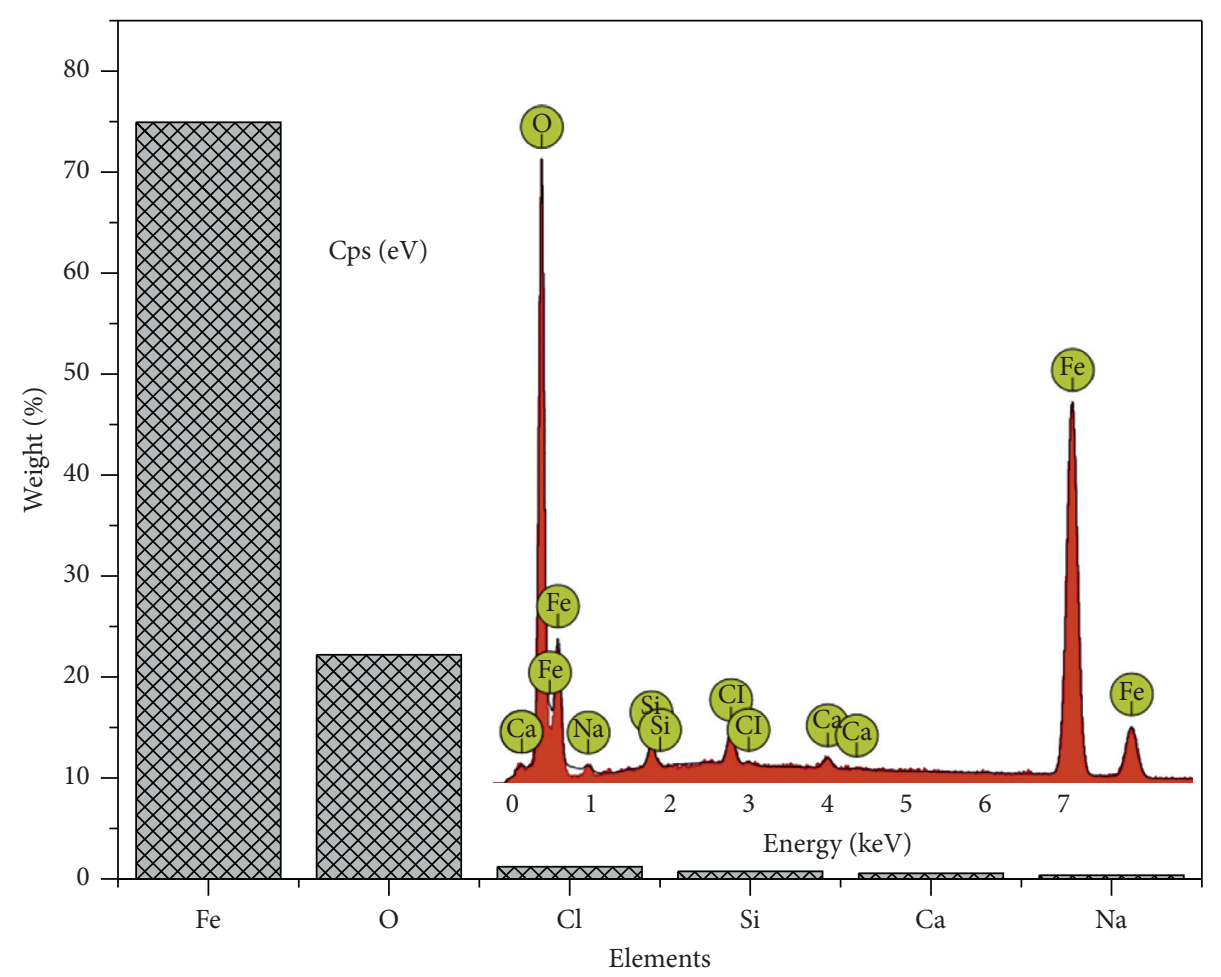

(a)

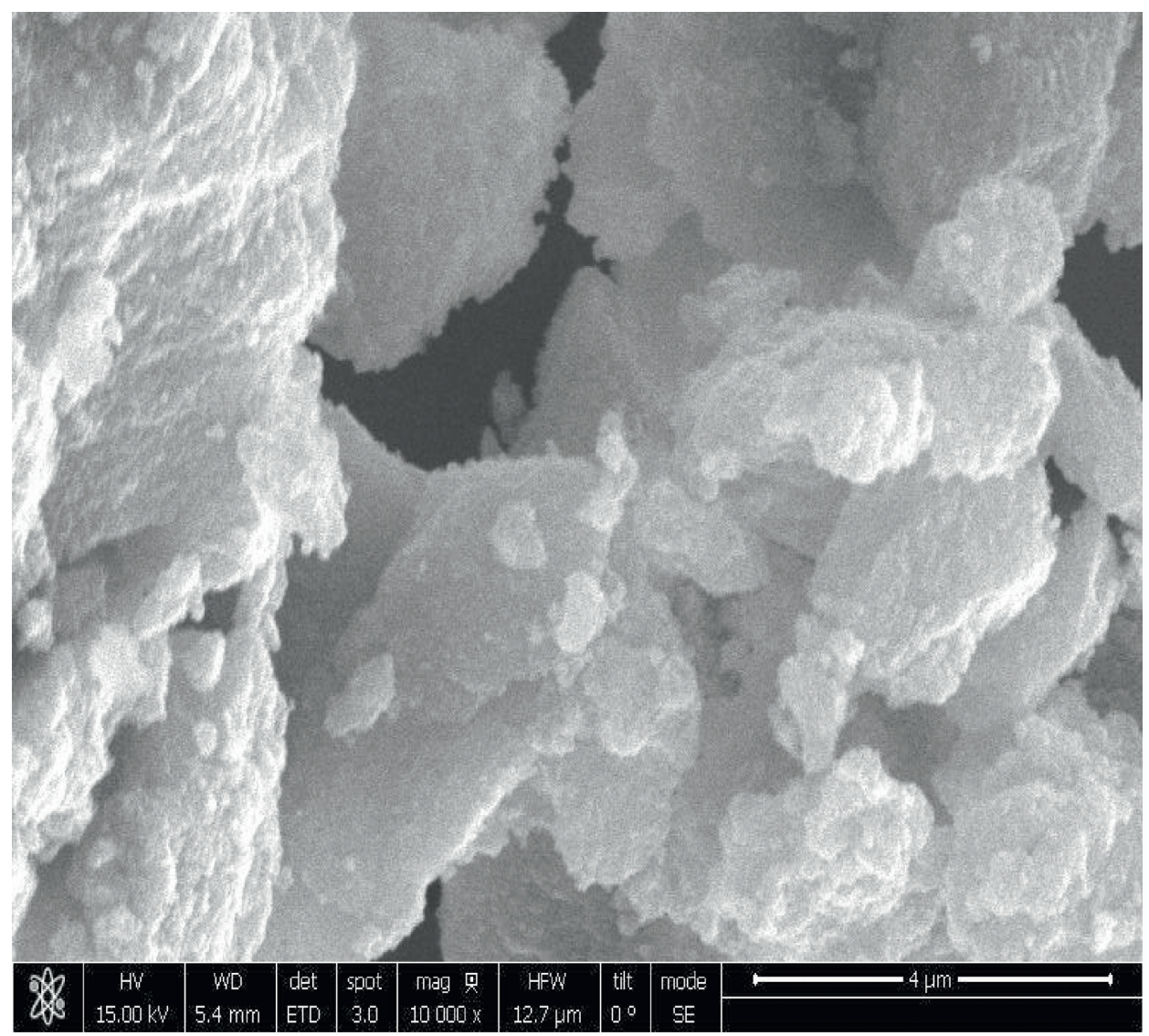

(b)

Figure 5: (a) EDX spectra of PP1- $\mathrm{Fe}_{3} \mathrm{O}_{4}$ NPs. (b) SEM of PP1- $\mathrm{Fe}_{3} \mathrm{O}_{4}$ NPs. 


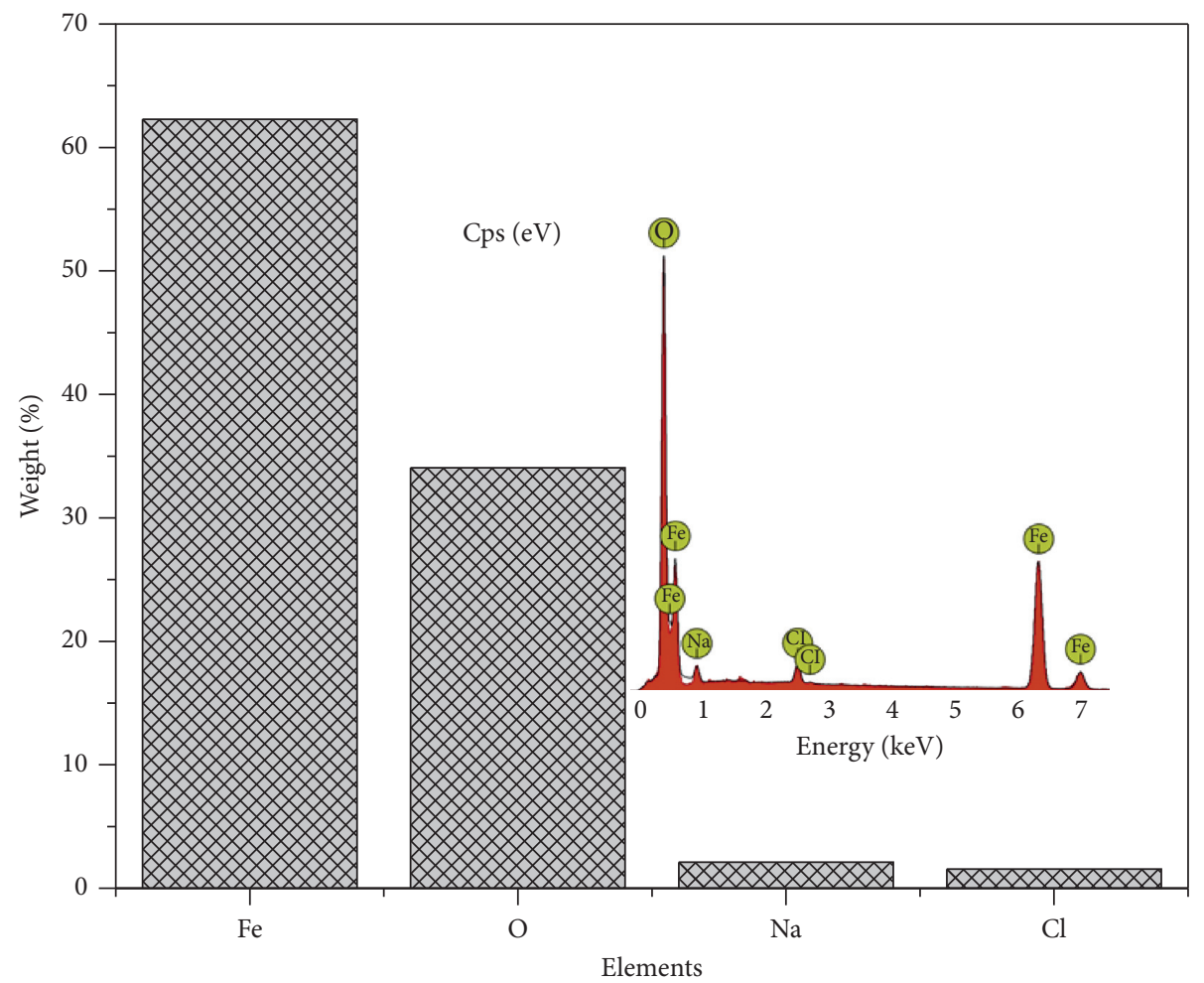

(a)

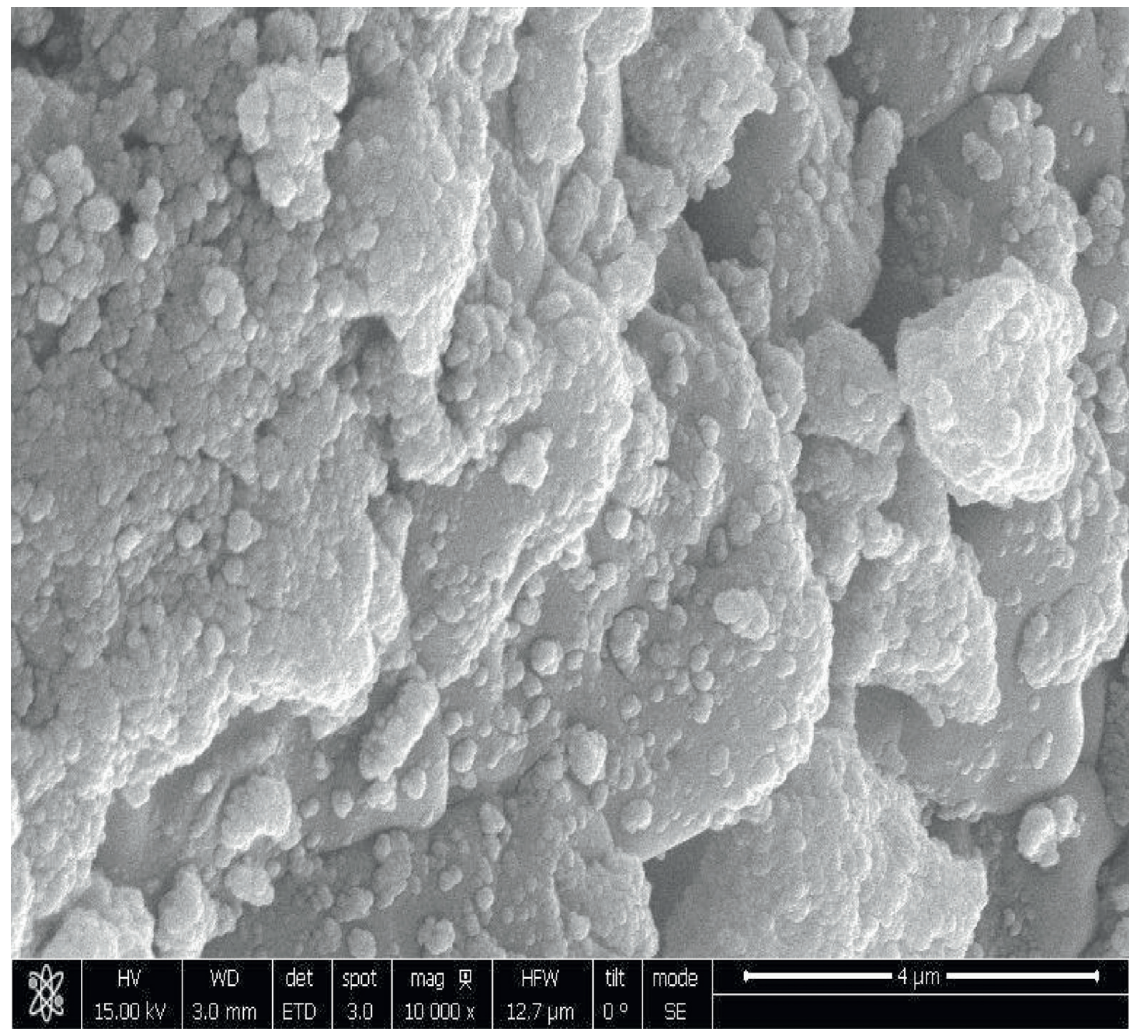

(b)

Figure 6: (a) EDX spectra of ML3- $\mathrm{Fe}_{3} \mathrm{O}_{4}$ NPs. (b) SEM of ML3- $\mathrm{Fe}_{3} \mathrm{O}_{4}$ NPs. 


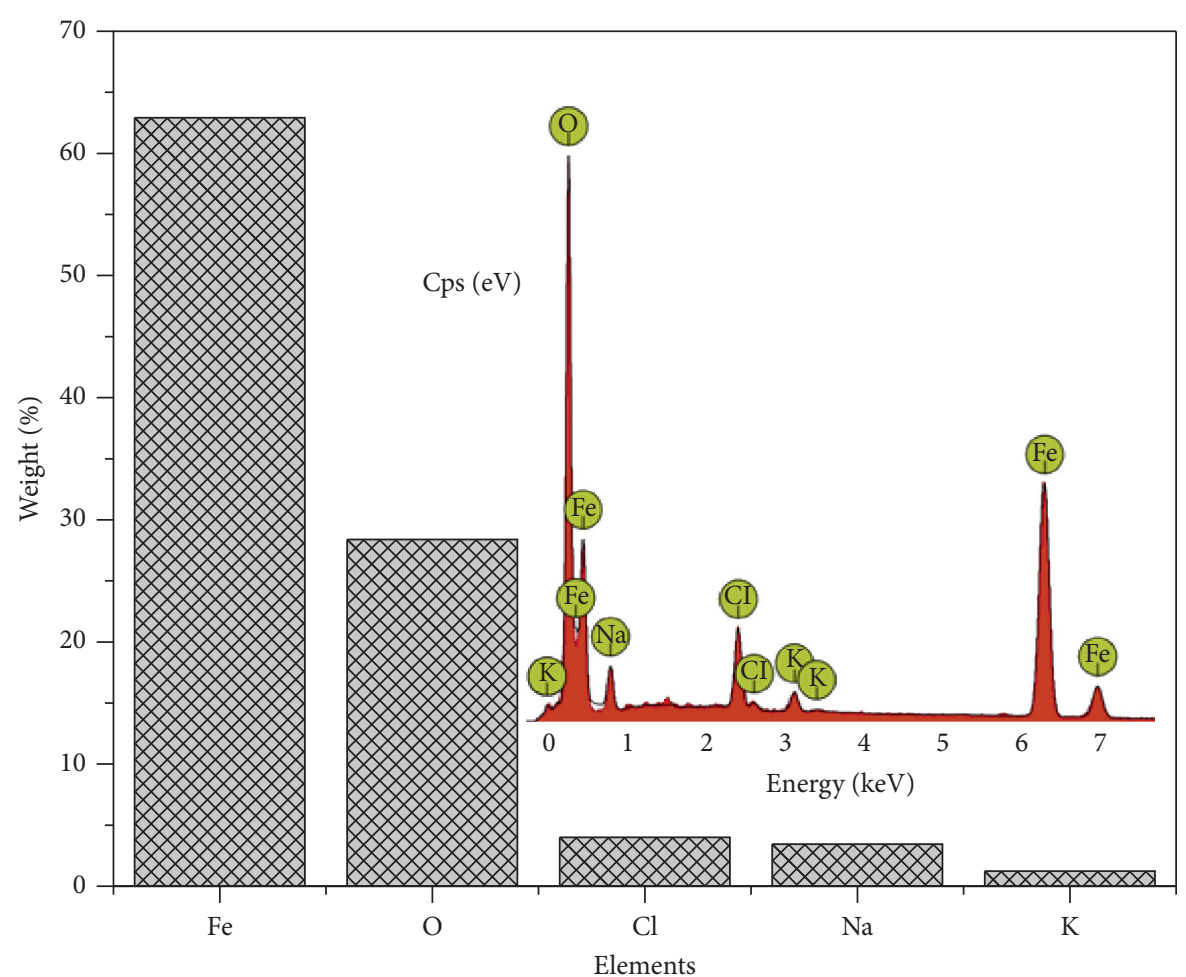

(a)

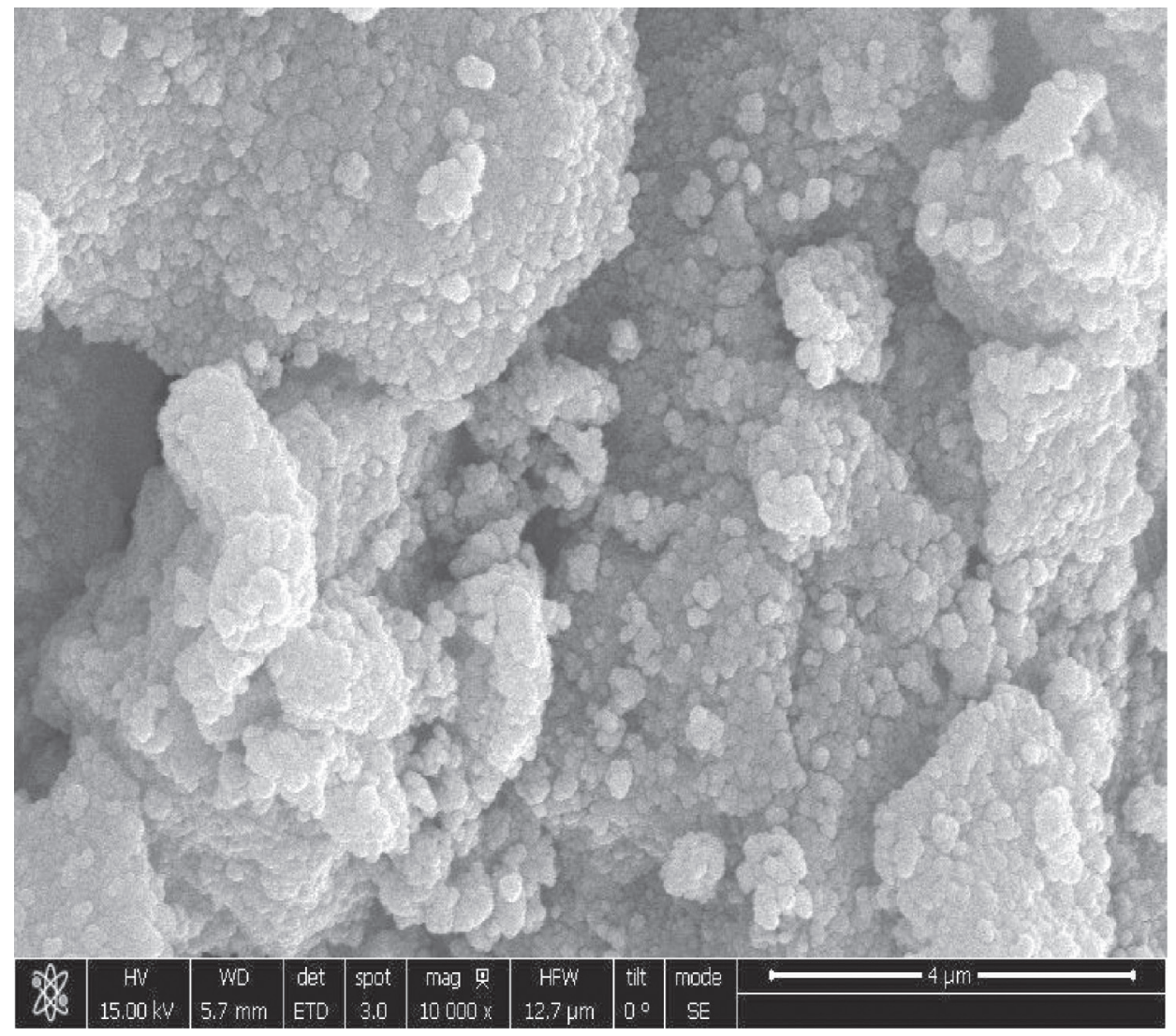

(b)

Figure 7: (a) EDX spectra of PP3- $\mathrm{Fe}_{3} \mathrm{O}_{4}$ NPs. (b) SEM of PP3- $\mathrm{Fe}_{3} \mathrm{O}_{4}$ NPs. 


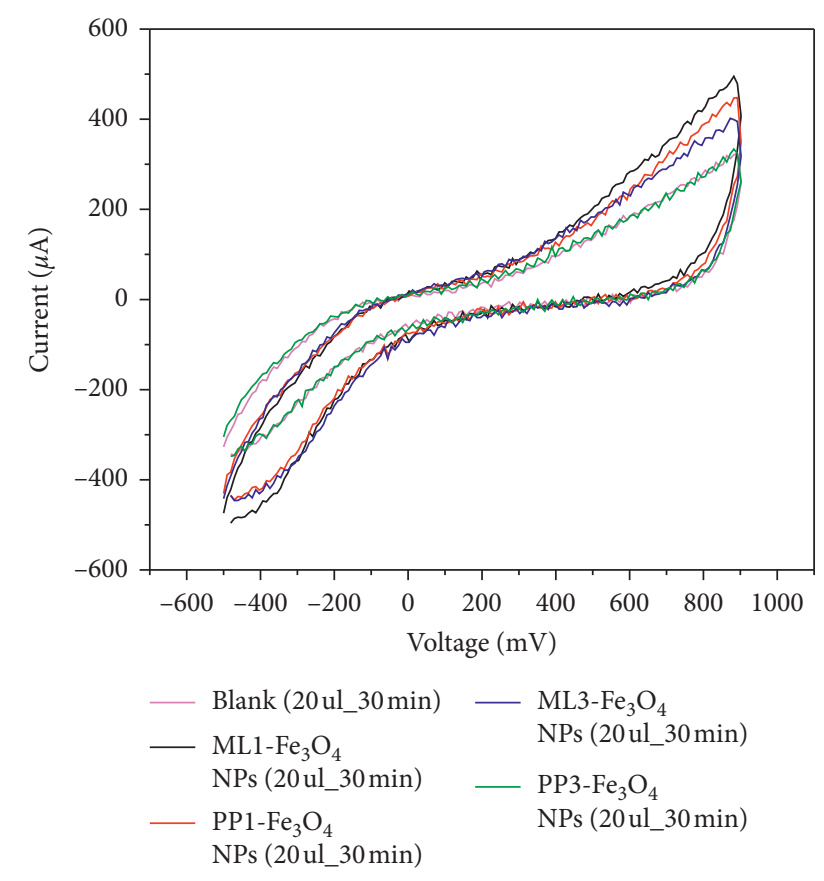

Figure 8: CV analysis plot after $20 \mu \mathrm{l}$ of sample suspension was added.

distinct differences confirm the XRD crystallite size differences calculated and attributed to the differences in molar concentrations of the precursors and plant extracts used for the nanoparticle synthesis.

3.4. $\mathrm{CV}$ and $\mathrm{IC}_{50}$ Analysis of Cells with $\mathrm{Fe}_{3} \mathrm{O}_{4}-\mathrm{NPs}$. The cyclic voltammetry $(\mathrm{CV})$ analysis conducted after every $30 \mathrm{~min}$ for $2 \mathrm{~h}$ displayed the influence of $\mathrm{Fe}_{3} \mathrm{O}_{4} \mathrm{NPs}$ on Hela cells. The voltammogram (Figure 8) revealed variation of anodic peak current which corresponds to the different sources of $\mathrm{Fe}_{3} \mathrm{O}_{4}$ NPs suspension interaction with the blank (PBS).The voltammogram indicates that all the different sources of $\mathrm{Fe}_{3} \mathrm{O}_{4}$ NPs are REDOX active materials. There were available free sites in the $\mathrm{Fe}_{3} \mathrm{O}_{4}$ NPs to accept electrons from the electrode during the oxidation half cycle.

Interactions of $\mathrm{Fe}_{3} \mathrm{O}_{4}$ NPs suspension from different sources with HeLa cells also showed REDOX activities. $\mathrm{ML1}-\mathrm{Fe}_{3} \mathrm{O}_{4}$ NPs showed higher anodic peak currents than the HeLa cells alone whereas $\mathrm{ML} 3-\mathrm{Fe}_{3} \mathrm{O}_{4}$ NPs showed peak currents lower than the HeLa cells alone. The peak current indicates that ML3-FeNPs proliferate through depolarization whereas $\mathrm{ML1}-\mathrm{Fe}_{3} \mathrm{O}_{4}$ NPs proliferate through polarization. Cellular activities with cancerous cells are usual with depolarization [32]. Thus, polarization signal obtained suggests inhibition of cancerous proliferation. For PP1$\mathrm{Fe}_{3} \mathrm{O}_{4} \mathrm{NPs}$ and PP3- $\mathrm{Fe}_{3} \mathrm{O}_{4} \mathrm{NPs}$, the anodic peak current was similar to $\mathrm{ML} 1-\mathrm{Fe}_{3} \mathrm{O}_{4} \mathrm{NPs}$ and $\mathrm{ML3}-\mathrm{Fe}_{3} \mathrm{O}_{4} \mathrm{NPs}$, respectively. The influence of nanoparticles on HeLa cells correlated with concentration and nanoparticulate (crystallite size) size of particles. Variation of concentration returned different peak currents that gave different electrochemical gradients which resulted in wavy patterns. The patterns are

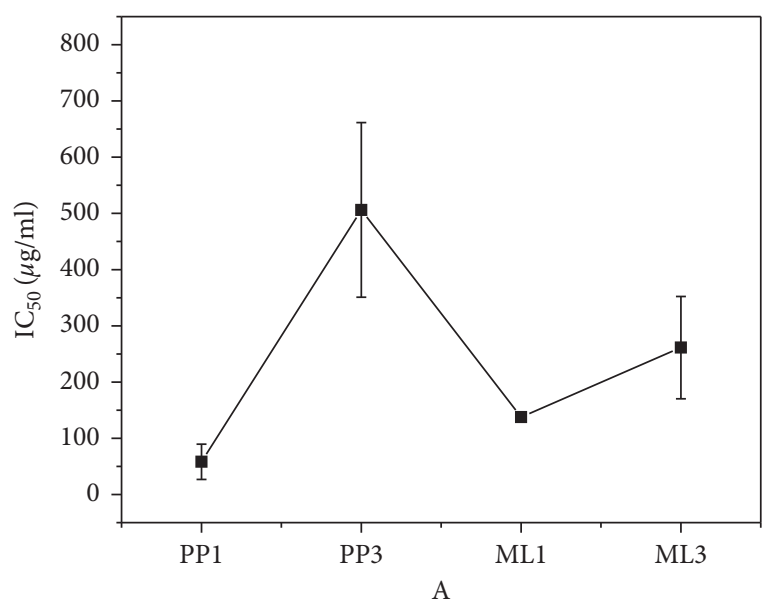

Figure 9: The particle potency to inhibit half of the HeLa cells. Low $\mathrm{IC}_{50}$ indicates high inhibitory potent.

similar to patterns of normal cellular activities [35]. The polarization of the cells corresponded to particles with smaller crystallite size whereas depolarization related to particles with larger crystallite sizes. It is suspected that the particles with the smaller crystallite size created high electrochemical gradient in the extracellular matrix for more ion outflow from the cytoplasm thereby inhibiting the cell depolarization signal. On the other hand, the larger crystallite particles are suspected to block the voltage gates of the ion channels. The blockage prevented more outflow of ions into the extracellular matrix.

From Figure 9, all the nanoparticles show inhibitory effect on the proliferation signal but with varying degrees; however, smaller calculated crystallites ML1- $\mathrm{Fe}_{3} \mathrm{O}_{4} \mathrm{NPs}$ and $\mathrm{PP} 1-\mathrm{Fe}_{3} \mathrm{O}_{4}$ NPs exhibited much lower $\mathrm{IC}_{50}$ values. The differences in bioactive molecules in the extract are suspected to have played a role in the inhibitory potential. From the $\mathrm{IC}_{50}$ studies, $\mathrm{PP} 1-\mathrm{Fe}_{3} \mathrm{O}_{4} \mathrm{NPs}$ is the most highly potent on the cells. The result showed that the particles with the highest potency are associated with smaller particle size.

\section{Conclusion}

The feasibility of synthesizing magnetic iron oxide particles from maize leave and plantain peels has been established. The precursor's molar ratio was varied to obtain four different particles: two from the maize leave $\left(\mathrm{ML1}-\mathrm{Fe}_{3} \mathrm{O}_{4} \mathrm{NPs}\right.$ and $\mathrm{ML} 3-\mathrm{Fe}_{3} \mathrm{O}_{4} \mathrm{NPs}$ ) and the other two from plantain peels (PP1- $\mathrm{Fe}_{3} \mathrm{O}_{4} \mathrm{NPs}$ and PP3- $\mathrm{Fe}_{3} \mathrm{O}_{4} \mathrm{NPs}$ ). The ML1-and PP1$\mathrm{Fe}_{3} \mathrm{O}_{4}$ NPs were prepared from higher molar ratios whereas ML3-and PP3- $\mathrm{Fe}_{3} \mathrm{O}_{4}$ NPs were of a lower molar ratio. Crystallographic information determined from the XRD patterns showed that the ML1 and PP1- $\mathrm{Fe}_{3} \mathrm{O}_{4} \mathrm{NPs}$ had lower crystallite size than that of ML3- and PP3- $\mathrm{Fe}_{3} \mathrm{O}_{4} \mathrm{NPs}$. These results affected the interaction of the nanoparticles with HeLa cells differently. The particles with the smallest crystallite sizes polarized the cells whereas the ones with the largest crystallite size depolarized the cells. IC50 studies show high potency of inhibition with the low crystalline 
particles compared to the large particles and, thus, the particles show potential in targeted cancer treatment.

\section{Data Availability}

The data used to support this research's findings are included within the manuscript.

\section{Conflicts of Interest}

The authors declare no conflicts of interest.

\section{Acknowledgments}

This work was supported through University of Ghana UGRF10 research grant and the Commonwealth Early Academic Fellowship and the Cambridge-Africa Partnership for Research Excellence (CAPREx) Fellowship Programs.

\section{References}

[1] C. He, D. Liu, and W. Lin, "Nanomedicine applications of hybrid nanomaterials built from metal-ligand coordination bonds: nanoscale metal-organic frameworks and nanoscale coordination polymers," Chemical Reviews, vol. 115, no. 19, pp. 11079-11108, 2015.

[2] B. R. Smith and S. S. Gambhir, "Nanomaterials for in vivo imaging," Chemical Reviews, vol. 117, no. 3, pp. 901-986, 2017.

[3] V. Shanmugam, S. Selvakumar, and C.-S. Yeh, "Near-infrared light-responsive nanomaterials in cancer therapeutics," Chemical Society Reviews, vol. 43, no. 17, pp. 6254-6287, 2014.

[4] S. Nazir, T. Hussain, A. Ayub, U. Rashid, and A. J. MacRobert, "Nanomaterials in combating cancer: therapeutic applications and developments," Nanomedicine: Nanotechnology, Biology and Medicine, vol. 10, no. 1, pp. 19-34, 2014.

[5] D. J. Bharali and S. A. Mousa, "Emerging nanomedicines for early cancer detection and improved treatment: current perspective and future promise," Pharmacology \& Therapeutics, vol. 128, no. 2, pp. 324-335, 2010.

[6] J. Q. Zhang, Z. R. Zhang, H. Yang, Q. Y. Tan, S. R. Qin, and X. L. Qiu, "Lyophilized paclitaxel magnetoliposomes as a potential drug delivery system for breast carcinoma via parenteral administration: in vitro and in vivo studies," Pharmaceutical Research, vol. 22, no. 4, pp. 573-583, 2005.

[7] J. Oh, M. D. Feldman, J. Kim et al., "Magneto-motive detection of tissue-based macrophages by differential phase optical coherence tomography," Lasers in Surgery and Medicine, vol. 39, no. 3, pp. 266-272, 2007.

[8] A. S. Teja and P.-Y. Koh, "Synthesis, properties, and applications of magnetic iron oxide nanoparticles," Progress in Crystal Growth and Characterization of Materials, vol. 55, no. 1-2, pp. 22-45, 2009.

[9] B. Xu, H. Dou, K. Tao et al., “"Two-in-one” fabrication of $\mathrm{Fe}_{3} \mathrm{O}_{4}$ /MePEG-PLA composite nanocapsules as a potential ultrasonic/MRI dual contrast agent," Langmuir, vol. 27, no. 19, pp. 12134-12142, 2011.

[10] X. Chen, R. Klingeler, M. Kath et al., "Magnetic silica nanotubes: synthesis, drug release, and feasibility for magnetic hyperthermia," ACS Applied Materials \& Interfaces, vol. 4, no. 4, pp. 2303-2309, 2012.

[11] V. Jassal, U. Shanker, and S. Gahlot, "Green synthesis of some iron oxide nanoparticles and their interaction with 2-amino, 3-amino and 4-aminopyridines," Materials Today: Proceedings, vol. 3, no. 6, pp. 1874-1882, 2016.

[12] B. Issa, I. Obaidat, B. Albiss, and Y. Haik, "Magnetic nanoparticles: surface effects and properties related to biomedicine applications," International Journal of Molecular Sciences, vol. 14, no. 11, pp. 21266-21305, 2013.

[13] T. Tatarchuk, M. Bououdina, J. J. Vijaya, and L. J. Kennedy, "Spinel ferrite nanoparticles: synthesis, crystal structure, properties, and perspective applications," in Proceedings of the International Conference on Nanotechnology and Nanomaterials, pp. 305-325, Springer, Lviv, Ukraine, August 2016.

[14] H. Jiao and H. Yang, "Controlled synthesis and magnetic properties of $\mathrm{Fe}_{3} \mathrm{O}_{4}$ walnut spherical particles and octahedral microcrystals," Science in China Series E: Technological Sciences, vol. 51, no. 11, pp. 1911-1920, 2008.

[15] J. H. Wu, S. P. Ko, H. L. Liu et al., "Sub $5 \mathrm{~nm} \mathrm{Fe}_{3} \mathrm{O}_{4}$ nanocrystals via coprecipitation method," Colloids and Surfaces A: Physicochemical and Engineering Aspects, vol. 313-314, pp. 268-272, 2008.

[16] M. N. Islam, J. R. Jeong, and C. Kim, "A facile route to sonochemical synthesis of magnetic iron oxide $\left(\mathrm{Fe}_{3} \mathrm{O}_{4}\right)$ nanoparticles," Thin Solid Films, vol. 519, no. 23, pp. 8277-8279, 2011.

[17] A. B. Seabra, P. Haddad, and N. Duran, "Biogenic synthesis of nanostructured iron compounds: applications and perspectives," IET Nanobiotechnology, vol. 7, no. 3, pp. 90-99, 2013.

[18] P. Mohanpuria, N. K. Rana, and S. K. Yadav, "Biosynthesis of nanoparticles: technological concepts and future applications," Journal of Nanoparticle Research, vol. 10, no. 3, pp. 507-517, 2008.

[19] Y. P. Yew, K. Shameli, M Miyake et al., "Green biosynthesis of superparamagnetic magnetite $\mathrm{Fe}_{3} \mathrm{O}_{4}$ nanoparticles and biomedical applications in targeted anticancer drug delivery system: a review," Arabian Journal of Chemistry, vol. 13, no. 1, pp. 2287-2308, 2020.

[20] J. Singh, T. Dutta, K. H. Kim, M. Rawat, P. Samddar, and P. Kumar, "Green synthesis of metals and their oxide nanoparticles: applications for environmental remediation," Journal of Nanobiotechnology, vol. 16, p. 84, 2018.

[21] M. Rai, A. Yadav, and A. Gade, "CRC 675-current trends in phytosynthesis of metal nanoparticles," Critical Reviews in Biotechnology, vol. 28, no. 4, pp. 277-284, 2008.

[22] A. K. Mittal, Y. Chisti, and U. C. Banerjee, "Synthesis of metallic nanoparticles using plant extracts," Biotechnology Advances, vol. 31, no. 2, pp. 346-356, 2013.

[23] J. Singh, T. Dutta, K. H. Kim, M. Rawat, P. Samddar, and P. Kumar, "“Green"synthesis of metals and their oxide nanoparticles: applications for environmental remediation," Journal of Nanobiotechnology, vol. 16, no. 1, p. 84, 2018.

[24] M. Sorbiun, E. Shayegan Mehr, A. Ramazani, and A. Mashhadi Malekzadeh, "Biosynthesis of metallic nanoparticles using plant extracts and evaluation of their antibacterial properties," Nanochemistry Research, vol. 3, no. 1, pp. 1-6, 2018.

[25] M. Martínez-Ballesta, Á. Gil-Izquierdo, C. García-Viguera, and R. Domínguez-Perles, "Nanoparticles and controlled delivery for bioactive compounds: outlining challenges for new "smart-foods" for health," Foods, vol. 7, no. 5, p. 72, 2018.

[26] A. D. Mubarak, N. Thajuddin, K. Jeganathan, and M. Gunasekaran, "Plant extract mediated synthesis of silver and gold nanoparticles and its antibacterial activity against clinically isolated pathogens," Colloids and Surfaces B: Biointerfaces, vol. 85, no. 2, pp. 360-365, 2011. 
[27] L. Blaney, "Magnetite $\left(\mathrm{Fe}_{3} \mathrm{O}_{4}\right)$ : properties, synthesis, and applications," The Lehigh Review, vol. 15, 2007.

[28] K. I. Lilova, C. I. Pearce, C. Gorski, K. M. Rosso, and A. Navrotsky, "Thermodynamics of the magnetite-ulvöspinel $\left(\mathrm{Fe}_{3} \mathrm{O}_{4}-\mathrm{Fe}_{2} \mathrm{TiO}_{4}\right)$ solid solution," American Mineralogist, vol. 97, no. 8-9, pp. 1330-1338, 2012.

[29] W. Jiang, K.-L. Lai, H. Hu et al., "The effect of $\left[\mathrm{Fe}^{3+}\right] /\left[\mathrm{Fe}^{2+}\right]$ molar ratio and iron salts concentration on the properties of superparamagnetic iron oxide nanoparticles in the water/ ethanol/toluene system," Journal of Nanoparticle Research, vol. 13, no. 10, pp. 5135-5145, 2011.

[30] A. Akbar, S. Riaz, M. Bashir, and S. Naseem, "Effect of $\mathrm{Fe}^{3+} /$ $\mathrm{Fe}^{2+}$ ratio on superparamagnetic behavior of spin coated iron oxide thin films," IEEE Transactions on Magnetics, vol. 50, no. 8, pp. 1-4, 2014.

[31] Á. De Jesús Ruíz-Baltazar, S. Y. Reyes-López, M. De Lourdes Mondragón-Sánchez, A. I. Robles-Cortés, and R. Pérez, "Eco-friendly synthesis of $\mathrm{Fe}_{3} \mathrm{O}_{4}$ nanoparticles: evaluation of their catalytic activity in methylene blue degradation by kinetic adsorption models," Results in Physics, vol. 12, pp. 989-995, 2019.

[32] E. H. Sujiono, J. Agus, S. Samnur, and K. Triyana, "Effects of molar ratios and sintering times on crystal structures and surface morphology of $\mathrm{Nd}_{1+x} \mathrm{FeO}_{3}$ oxide alloy prepared by using solid reaction method," Materials Science and Engineering, vol. 367, no. 1, Article ID 012056, 2018.

[33] S. Moradi, P. Aberoomand-Azar, S. Raeis-Farshid, S. AbediniKhorrami, and M. H. Givianrad, "The effect of different molar ratios of $\mathrm{ZnO}$ on characterization and photocatalytic activity of $\mathrm{TiO}_{2} / \mathrm{ZnO}$ nanocomposite," Journal of Saudi Chemical Society, vol. 20, no. 4, pp. 373-378, 2016.

[34] A. M. Awwad and N. M. Salem, "A green and facile approach for synthesis of magnetite nanoparticles," Nanoscience and Nanotechnology, vol. 2, no. 6, pp. 208-213, 2012.

[35] B. O. Asimeng, E. K. Tiburu, E. Effah Kaufmann et al., "Electrochemical evaluation of ion substituted-hydroxyapatite on HeLa cells plasma membrane potential," Cogent Engineering, vol. 6, no. 1, Article ID 1614756, 2019. 